\title{
Pengaruh Pembenaran Medis tentang Kapan Kehidupan Dimulai Terhadap Pengaturan Hukum tentang Anak dalam Kandungan ${ }^{1}$
}

\author{
Paulinus Soge \\ Fakultas Hukum Universitas Atma Jaya Yogyakarta \\ J1. Mrican Baru 2855281 Yogyakarta \\ soge@mail.uajy.ac.id
}

\begin{abstract}
The existence of abortion is more frequent in cities than in villages, and most of abortions are done deliberatively, especially in the cities. The problems which will be studied are: First, when does life begin based on the medical study? Second, how should the prevailing laws (ius constiuendum) be to protect the unborn child? Related to the protection for unborn child, the research using normative method has already been conducted. The research result shows that: first, life begins since the conception based on the medical finding. Second, as the result, Article 75 verse (2) $b$ of Law of Health both horizontally and vertically is not synchronous with the prevailing regulations of law. For the legal assurance, Article 75 verse (2) b of Law of Health needs to be reviewed.
\end{abstract}

Key words: Unborn child, medical finding, legal protection, legal assurance.

\begin{abstract}
Abstrak
Kejadian aborsi lebih tinggi di perkotaan dibanding di pedesaan, dan sebagian besar aborsi merupakan aborsi sengaja, terutama di kota. Permasalahan yang hendak diteliti: Pertama, kapan kehidupan itu dimulai berdasarkan kajian medis? Kedua, bagaimana hukum yang seharusnya berlaku (ius constituendum) untuk memberikan perlindungan terhadap anak dalam kandungan? Berkaitan dengan perlindungan terhadap anak dalam kandungan telah dilakukan penelitian dengan menggunakan metode normatif. Hasil penelitian menunjukkan bahwa: pertama, kehidupan telah dimulai sejak konsepsi berdasarkan temuan medis. Maka sejak itu perlindungan hukum harus diberikan kepada anak dalam kandungan. Kedua, akibatnya Pasal 75 ayat (2) b Undang-Undang Kesehatan baik secara horizontal maupun vertikal tidak sinkron dengan peraturan hukum yang berlaku. Demi kepastian hukum Pasal 75 ayat (2) b Undang-Undang Kesehatan perlu ditinjau kembali.
\end{abstract}

Kata kunci : Anak dalam kandungan, temuan medis, perlindungan hukum, kepastian hukum.

${ }^{1}$ Penelitian/riset ini didanai oleh Direktorat Jendral Pendidikan Tinggi Direktorat Penelitian dan Pengabdian Kepada Masyarakat, 2011 


\section{Pendahuluan}

Law reform atau pembaharuan hukum di Indonesia merupakan suatu usaha yang telah dimulai sejak bangsa Indonesia memproklamasikan kemerdekaannya pada 17 Agustus 1945. Pasal II Aturan Peralihan UUD 1945 menentukan: “Segala badan negara dan peraturan yang ada masih langsung berlaku, selama belum diadakan yang baru menurut Undang-Undang Dasar ini". Dari bunyi Pasal II Aturan Peralihan UUD 1945 tersebut di atas, dapat diketahui bahwa sejak berdirinya negara Republik Indonesia ini, bangsa Indonesia telah mempunyai ide untuk memiliki perundang-undangan sendiri yang dibentuk berdasarkan UUD 1945.

Usaha pembaharuan hukum di Indonesia yang sudah dimulai sejak lahirnya UUD 1945 tentunya tidak boleh dilepaskan dari politik hukum yang bertugas untuk meneliti perubahan-perubahan yang perlu diadakan terhadap hukum yang ada agar supaya memenuhi kebutuhan-kebutuhan baru di dalam masyarakat. Politik hukum tersebut meneruskan arah perkembangan tertib hukum, dari “ius constitutum” yang bertumpu pada kerangka landasan hukum yang dahulu menuju ke penyusunan "ius constituendum" atau hukum pada masa yang akan datang. ${ }^{2}$

Pendapat Soehardjo, Ss., di atas mendapat penegasan dari Bellefroid ${ }^{3}$ di dalam bukunya Inleiding Tot De Rechtswtenschap In Nederland, yang menyatakan bahwa politik hukum (rechtpolitiek) merupakan cabang ilmu hukum yang menyelidiki perubahan pada hukum yang ada sekarang ini untuk memenuhi tuntutan baru dari masyarakat dan terus mendorong pertumbuhan peraturan hukum yang berlaku saat ini "ius constitutum" menjadi "ius constituendum".

Penyusunan ius constituendum atau hukum pada masa yang akan datang tersebut harus tetap berpegang pada landasan dan tujuan yang ingin dicapai yaitu "melindungi segenap bangsa Indonesia dan untuk memajukan kesejahteraan umum berdasarkan Pancasila". Inilah garis kebijaksanaan umum yang menjadi landasan dan sekaligus tujuan dari politik hukum di Indonesia. Ini pulalah yang menjadi landasan dan tujuan dari setiap usaha pembaharuan hukum, termasuk pembaharuan di bidang hukum pidana dan kebijakan penanggulangan kejahatan di Indonesia. ${ }^{4}$

${ }^{2}$ Soehardjo, Ss., Politik. Hukum dan Pelaksanaannya dalam Negara Republik Indonesia, Fakultas Hukum Undip, Semarang, tanpa tahun, hlm. 2.

${ }^{3}$ Mr. J.P.H. Bellefroid, Inleiding Tot De Rechtswetenschap In Nederland, Dekker \& Van de Vegt N.V., Nijmegen, 1953, hlm. 17.

${ }^{4}$ Barda Nawawi Arief, Penetapan Pidana Penjara Dalam Rangka Usaha Penanggulangan Kejahatan, Universitas Padjadjaran, Bandung, 1986, hlm. 3. 
Salah satu usaha pembaharuan hukum pidana dan kebijakan penanggulangan kejahatan sebagaimana diuraikan di atas, ialah pembaharuan hukum pidana dan kebijakan penanggulangan kejahatan yang berkaitan dengan anak dalam kandungan. Usaha yang demikian ini perlu dilakukan karena menurut hasil penelitian Budi Utomo dkk., ${ }^{5}$ ditemukan angka kejadian 2 juta kasus aborsi per tahun, berarti 37 aborsi per 1000 wanita usia 15-19 tahun, atau 43 aborsi per 100 kelahiran hidup, atau 30\% dari kehamilan. Angka ini menunjukkan betapa besar jumlah kehamilan yang tidak diinginkan (KTD).

Hasil penelitian tersebut juga menunjukkan bahwa kejadian aborsi lebih tinggi di perkotaan dibanding di pedesaan, dan sebagian besar aborsi merupakan aborsi sengaja, terutama di kota. Banyak kejadian aborsi merupakan aborsi tak aman. Data menunjukkan bahwa peran dukun bayi dalam pelayanan aborsi masih besar, apalagi di pedesaan. Demikian pula banyak penyedia pelayanan lain yang beroperasi secara sembunyi-sembunyi, yang kemungkinan besar terkait dengan aborsi tidak aman.

Fenomena ini menunjukkan adanya perlakuan yang keliru dari sebagian warga masyarakat terhadap anak yang masih berada dalam kandungan. Perlakuan yang keliru tersebut dapat disebabkan karena kurang pahamnya warga masyarakat tentang kapan kehidupan itu dimulai. Oleh karena itu diperlukan analisis medis tentang awal kehidupan yang akan sangat membantu menyadarkan warga masyarakat untuk memelihara kehidupan insani. Selain itu, analisis yang demikian itu juga akan sangat membantu hukum, khususnya hukum pidana dalam upaya memberikan perlindungan terhadap anak dalam kandungan.

\section{Rumusan Masalah}

Bertolak dari latar belakang masalah di atas, maka dapat dirumuskan dua permasalahan pokok, yakni: Pertama, kapan kehidupan itu dimulai berdasarkan kajian medis? Kedua, bagaimana hukum yang seharusnya berlaku (ius constituendum) untuk memberikan perlindungan terhadap anak dalam kandungan?

${ }^{5}$ Budi Utomo, dkk., Insiden dan Aspek. Psiko-Sosial Aborsi di Indonesia (Prosiding Seminar), Pusat Penelitian Kesehatan Universitas Indonesia \& United Nations Population Fund (UNPA), Jakarta, 2001, hlm. 30-31. 


\section{Tujuan Penelitian}

Penelitian ini difokuskan pada dua tujuan utama, yakni: pertama, untuk memahami kajian medis mengenai kapan kehidupan dimulai. Kedua, untuk mengetahui dan menganalisis bagaimana hukum yang seharusnya berlaku untuk memberikan perlindungan terhadap anak dalam kandungan.

\section{Metode Penelitian}

Penelitian ini merupakan penelitian hukum normatif, yaitu penelitian terhadap data sekunder di bidang hukum yang dipadukan dengan data sekunder di bidang medis. Data sekunder baik di bidang hukum tentang ketentuan-ketentuan hukum yang mengatur anak dalam kandungan maupun di bidang medis tentang kapan kehidupan dimulai diperoleh melalui studi pustaka.

Data sekunder di bidang hukum bersumber dari bahan hukum primer berupa perundang-undangan yang berkaitan dengan perlindungan anak dalam kandungan serta bahan hukum sekunder berupa literatur dan pendapat para pakar yang berkaitan dengan permasalahan yang diteliti. Sedangkan data sekunder di bidang medis bersumber dari temuan para pakar di bidang medis tentang kapan kehidupan dimulai yang diperoleh dari berbagai literatur di bidang medis.

Data sekunder baik di bidang hukum maupun di bidang medis yang terkumpul dianalisis secara kualitatif, yaitu analisis yang didasarkan atas nilai, kualitas dan keadaan data yang diperoleh. Dengan kata lain pencarian kebenaran dalam penelitian ini didasarkan dan diukur dengan kualitas, nilai dan keadaan data yang bersangkutan.

\section{Hasil Penelitian dan Pembahasan}

Di dalam hukum positif Indonesia ketentuan hukum yang berkaitan dengan hak anak dalam kandungan terdapat dalam UUD 1945, Kitab Undang-Undang Hukum Perdata (KUHPdt.), UU No. 39 Tahun 1999 tentang Hak Asasi Manusia (UUHAM), dan UU No. 23 Tahun 2002 tentang Perlindungan Anak (UUPA).

Alinea IV Pembukaan UUD 1945 memuat pernyataan: “Kemudian daripada itu untuk membentuk suatu Pemerintah Negara Indonesia yang melindungi segenap bangsa Indonesia dan seluruh tumpah darah Indonesia dan untuk memajukan 
kesejahteraan umum, mencerdaskan kehidupan bangsa, dan ikut melaksanakan ketertiban dunia yang berdasarkan kemerdekaan, perdamaian abadi dan keadilan sosial, maka disusunlah Kemerdekaan Kebangsaan Indonesia itu dalam suatu Undang-Undang Dasar Negara Indonesia yang berkedaulatan rakyat dengan berdasarkan kepada Ketuhanan Yang Maha Esa, Kemanusiaan yang adil dan beradab, Persatuan Indonesia dan Kerakyatan yang dipimpin oleh hikmat kebijaksanaan dalam Permusyawaratan/Perwakilan, serta dengan mewujudkan suatu Keadilan sosial bagi seluruh rakyat Indonesia."

Dari pernyataan pada alinea IV Pembukaan UUD 1945 tersebut terlihat jelas bahwa salah satu tujuan didirikannya Negara Republik Indonesia dan menjadi landasan politik hukum Indonesia adalah "melindungi segenap bangsa Indonesia dan seluruh tumpah darah Indonesia". Begitu umumnya perlindungan yang diberikan oleh negara yaitu kepada segenap bangsa Indonesia dan tumpah darah Indonesia, maka dapat dikatakan bahwa perlindungan itu tidak hanya diberikan kepada orang pada umumnya, tetapi juga diberikan kepada anak yang masih berada dalam kandungan.

Perlindungan terhadap segenap bangsa Indonesia dan seluruh tumpah darah Indonesia itu di dalam UUD 1945 yang asli tidak diatur secara jelas, namun setelah diamandemen mendapat penegasan dalam Pasal 28A yang mengatur tentang perlindungan terhadap orang pada umumnya dan Pasal 28B ayat (2) yang mengatur tentang perlindungan anak pada khususnya. Pasal 28A mengatakan "Setiap orang berhak untuk hidup serta berhak mempertahankan hidup dan kehidupannya". Sedangkan Pasal 28B ayat (2) mengatakan "Setiap anak berhak atas kelangsungan hidup, tumbuh dan berkembang serta berhak atas perlindungan dari kekerasan dan diskriminasi".

Kemudian di dalam Pasal 2 Buku Kesatu KUHPdt., menentukan bahwa anak yang ada dalam kandungan seorang perempuan, dianggap sebagai telah dilahirkan, bilamana juga kepentingan si anak menghendakinya. Mati sewaktu dilahirkannya, dianggaplah ia tidak pernah ada."

Anak sebagaimana disebutkan dalam Pasal 28B ayat (2) UUD 1945 diberikan definisi dan diatur tentang hak-haknya dalam UUHAM. Di dalam Pasal 1 angka 5 UUHAM diberikan pengertian anak sebagai berikut: Anak adalah setiap manusia yang berusia di bawah 18 (delapan belas) tahun dan belum menikah, termasuk anak yang masih berada dalam kandungan apabila hal tersebut adalah demi 
kepentingannya. Mengenai hak dan perlindungan terhadap anak, termasuk anak yang masih berada dalam kandungan diatur dalam Pasal 52 dan Pasal 53. Berdasarkan Pasal 52 ditentukan bahwa : 1. setiap anak berhak atas perlindungan oleh orang tua, keluarga, masyarakat dan negara; 2 . hak anak adalah hak asasi manusia dan untuk kepentingannya hak anak itu diakui dan dilindungi oleh hukum bahkan sejak dalam kandungan.

Sedangkan di dalam Pasal 53 ditentukan: 1. setiap anak sejak dalam kandungan, berhak untuk hidup, mempertahankan hidup, dan meningkatkan taraf kehidupannya; 2. setiap anak sejak kelahirannya, berhak atas suatu nama dan status kewarganegaraan.

Di samping mencantumkan hak dan perlindungan terhadap anak, termasuk anak yang masih berada dalam kandungan, UUHAM juga mengatur tentang kewajiban dan tanggung jawab orang tua, keluarga, masyarakat, pemerintah, dan negara untuk memberikan perlindungan pada anak. Tanggung jawab orang tua dan keluarga diatur dalam Pasal 56, 57, 58, dan 59, tanggung jawab masyarakat diatur dalam Pasal 100, 101, 102, dan 103, tanggung jawab pemerintah diatur dalam Pasal 71 dan 72, dan tanggung jawab negara untuk mengembangkan dan meningkatkan perlindungan serta penegakan HAM melalui suatu lembaga yang secara khusus dibentuk untuk mengemban tugas tersebut yaitu KOMNAS HAM sebagaimana diatur dalam Bab VII Pasal 75 sampai Pasal 99.

Anak sebagaimana disebutkan dalam Pasal 28B ayat (2) UUD 1945 juga diberikan definisi dan diatur tentang hak-haknya dalam UUPA. Di dalam Penjelasan Umum UUPA antara lain dinyatakan bahwa meskipun UUHAM telah mencantumkan hak tentang anak, pelaksanaan kewajiban dan tanggung jawab orang tua, keluarga, masyarakat, pemerintah, dan negara untuk memberikan pelindungan pada anak, masih diperlukan suatu undang-undang mengenai perlindungan anak sebagai landasan yuridis bagi pelaksanaan kewajiban dan tanggung jawab tersebut. Dengan demikian, pembentukan undang-undang ini didasarkan pada pertimbangan bahwa perlindungan anak dalam segala aspeknya merupakan bagian dari kegiatan pembangunan nasional, khususnya dalam memajukan kehidupan berbangsa dan bernegara.

Orang tua, keluarga, dan masyarakat bertanggung jawab untuk menjaga dan memelihara hak asasi tersebut sesuai dengan kewajiban yang dibebankan oleh hukum. Demikian pula dalam rangka penyelenggaraan perlindungan anak, negara 
dan pemerintah bertanggung jawab menyediakan fasilitas dan aksesibilitas bagi anak, terutama dalam menjamin pertumbuhan dan perkembangannya secara optimal dan terarah.

Undang-undang ini menegaskan bahwa pertanggungjawaban orang tua, keluarga, masyarakat, pemerintah dan negara merupakan rangkaian kegiatan yang dilaksanakan secara terus menerus dengan terlindunginya hak-hak anak. Rangkaian kegiatan tersebut harus berkelanjutan dan terarah guna menjamin pertumbuhan dan perkembangan anak, baik fisik, mental, spiritual maupun sosial. Tindakan ini dimaksudkan untuk mewujudkan kehidupan terbaik bagi anak yang diharapkan sebagai penerus bangsa yang potensial, tangguh, memiliki nasionalisme yang dijiwai oleh akhlak mulia dan nilai Pancasila, serta berkemauan keras menjaga kesatuan dan persatuan bangsa dan negara.

Upaya perlindungan anak perlu dilakukan sedini mungkin, yakni sejak dari janin dalam kandungan sampai anak berumur 18 (delapan belas) tahun. Bertitik tolak dari konsepsi perlindungan anak yang utuh, menyeluruh dan komprehensif, undang-undang ini meletakkan kewajiban memberikan perlindungan kepada anak berdasarkan asas non diskriminasi; kepentingan yang terbaik bagi anak; hak untuk hidup, kelangsungan hidup, dan perkembangan; dan penghargaan terhadap pendapat anak.

Dalam melakukan pembinaan, pengembangan dan perlindungan anak, perlu peran masyarakat, baik melalui lembaga perlindungan anak, lembaga keagamaan, lembaga swadaya masyarakat, organisasi kemasyarakatan, organisasi sosial, dunia usaha, media massa, atau lembaga pendidikan. Definisi tentang anak, perlindungan anak, dan hak anak masing-masing diberikan pada Pasal 1 angka 1, angka 2, dan angka 12 UU No. 23 Tahun 2002 tentang Perlindungan Anak (UUPA).

Pasal 1 angka 1 menentukan, yaitu : "Anak adalah seseorang yang belum berusia 18 (delapan belas) tahun, termasuk anak yang masih dalam kandungan". Pasal 1 angka 2 menentukan: "Perlindungan anak adalah segala kegiatan untuk menjamin dan melindungi anak dan hak-haknya agar dapat hidup, tumbuh, berkembang, dan berpartisipasi secara optimal sesuai dengan harkat dan martabat kemanusiaan, serta mendapat perlindungan dari kekerasan dan diskriminasi". Pasal 1 angka 12 menentukan bahwa: "Hak anak adalah bagian dari hak asasi manusia yang wajib dijamin, dilindungi, dan dipenuhi oleh orang tua, keluarga, masyarakat, pemerintah dan negara". 
Dari penjelasan umum dan definsi-definisi tersebut di atas dapat disimak bahwa hak anak dalam kandungan atau janin merupakan bagian dari hak asasi manusia yang wajib dijamin, dilindungi, dan dipenuhi oleh orang tua, keluarga, masyarakat, pemerintah dan negara agar dapat hidup, tumbuh, berkembang, dan berpartisipasi secara optimal sesuai dengan harkat dan martabat kemanusiaan, serta mendapat perlindungan dari kekerasan dan diskriminasi sebagaimana ditegaskan dalam Pasal 2, Pasal 3, dan Pasal 4.

Pasal 2 menentukan: "Penyelenggaraan perlindungan anak berasaskan Pancasila dan berlandaskan Undang-Undang Dasar Negara Republik Indonesia Tahun 1945 serta prinsip-prinsip dasar Konvensi Hak-Hak Anak meliputi: non diskriminasi; kepentingan yang terbaik bagi anak; hak untuk hidup, kelangsungan hidup, dan perkembangan; dan penghargaan terhadap pendapat anak".

Pasal 3 menentukan: "Perlindungan anak bertujuan untuk menjamin terpenuhinya hak-hak anak agar dapat hidup, tumbuh, berkembang, dan berpartisipasi secara optimal sesuai dengan harkat dan martabat kemanusiaan, serta mendapat perlindungan dari kekerasan dan diskriminasi, demi terwujudnya anak Indonesia yang berkualitas, berakhlak mulia, dan sejahtera".

Pasal 4 menyatakan bahwa: "Setiap anak berhak untuk dapat hidup, tumbuh, berkembang, dan berpartisipasi secara wajar sesuai dengan harkat dan martabat kemanusiaan, serta mendapat perlindungan dari kekerasan dan diskriminasi".

Ketentuan Pasal 2, 3, dan 4 ini didukung oleh ketentuan Pasal 44 dan Pasal 45. Pasal 44 menentukan: (1) pemerintah wajib menyediakan fasilitas dan menyelenggarakan upaya kesehatan yang komprehensif bagi anak, agar setiap anak memperoleh derajat kesehatan yang optimal sejak dalam kandungan; (2) penyediaan fasilitas dan penyelenggaraan upaya kesehatan secara komprehensif sebagaimana dimaksud dalam ayat (1) didukung oleh peran serta masyarakat; (3) upaya kesehatan yang komprehensif sebagaimana dimaksud dalam ayat (1) meliputi upaya promotif, preventif, kuratif, dan rehabilitatif, baik untuk pelayanan kesehatan dasar maupun rujukan; (4) upaya kesehatan yang komprehensif sebagaimana dimaksud dalam ayat (1) diselenggarakan secara cuma-cuma bagi keluarga yang tidak mampu; (5) pelaksanaan ketentuan sebagaimana dimaksud dalam ayat (1), ayat (2), ayat (3), dan ayat (4) disesuaikan dengan ketentuan peraturan perundang-undangan yang berlaku.

Sedangkan Pasal 45 menentukan: (1) orang tua dan keluarga bertanggung jawab menjaga kesehatan anak dan merawat anak sejak dalam kandungan; (2) dalam hal 
orang tua dan keluarga yang tidak mampu melaksanakan tanggung jawab sebagaimana dimaksud dalam ayat (1), maka pemerintah wajib memenuhinya; (3) kewajiban sebagaimana dimaksud dalam ayat (2), pelaksanaannya dilakukan sesuai dengan ketentuan peraturan-perundangan yang berlaku.

Undang-Undang ini mengamanatkan pembentukan Komisi Perlindungan Anak Indonesia yang bersifat independen dalam rangka meningkatkan penyelenggaraan perlindungan anak (Pasal 74). Komisi ini diangkat dan diberhentikan oleh Presiden setelah mendapat pertimbangan dari DPR untuk jabatan 3 (tiga) tahun dan dapat diangkat kembali untuk 1 (satu) kali masa jabatan (Pasal 75 ayat [3]). Komisi ini mempunyai dua tugas sebagaimana diatur di dalam Pasal 76 yaitu: melakukan sosialisasi seluruh ketentuan peraturan perundang-undangan yang berkaitan dengan perlindungan anak, mengumpulkan data dan informasi, menerima pengaduan masyarakat, melakukan penelaahan, pemantauan, evaluasi, dan pengawasan terhadap penyelenggaraan perlindungan anak; memberikan laporan, saran, masukan, dan pertimbangan kepada Presiden dalam rangka perlindungan anak.

Ketentuan pidana di dalam Undang-Undang ini diatur dalam Pasal 77 sampai Pasal 90. Ketentuan pidana yang berkaitan dengan tindak pidana terhadap anak dalam kandungan atau janin terdapat dalam Pasal 80 yang menentukan: (1) setiap orang yang melakukan kekejaman, kekerasan atau ancaman kekerasan, atau penganiayaan terhadap anak dipidana dengan pidana penjara selama 3 (tiga) tahun 6 (enam) bulan dan/atau denda paling banyak Rp. 72.000.000,00 (tujuh puluh dua juta rupiah); (2) dalam hal anak sebagaimana dimaksud dalam ayat (1) luka berat, maka pelaku dipidana dengan pidana penjara paling lama 10 (sepuluh) tahun dan/atau denda paling banyak Rp. 100.000.000,00 (seratus juta rupiah); (3) dalam hal anak sebagaimana dimaksud dalam ayat (2) mati, maka pelaku dipidana dengan pidana penjara paling lama 5 (lima) tahun dan/atau denda paling banyak Rp. 200.000.000,00 (dua ratus juta rupiah); (4) pidana ditambah sepertiga dari ketentuan sebagaimana dimaksud dalam ayat (1), ayat (2), dan ayat (3) apabila yang melakukan penganiayaan tersebut orang tuanya.

Ketentuan pidana yang langsung berkaitan dengan anak yang masih berada dalam kandungan atau janin yaitu Pasal 80 ayat (2) dan (4). Luka berat sebagaimana disebut dalam Pasal 80 ayat (2) menurut ketentuan Pasal 90 KUHP antara lain berarti matinya atau gugurnya kandungan seorang ibu. Apabila matinya atau gugurnya kandungan seorang ibu itu disebabkan oleh orang tuanya sendiri, maka berdasarkan Pasal 80 ayat (4), pidana diperberat sepertiganya. 
Bertolak dari uraian di atas dapat diketahui bahwa hukum positif Indonesia secara perlahan-lahan telah menyesuaikan diri dengan perkembangan ilmu pengetahuan tentang embrio pada ilmu kedokteran. Ketentuan dalam KUHPdt. yang masih samarsamar mengenai apakah anak dalam kandungan sudah menjadi manusia atau orang telah mendapat penegasan di dalam UUHAM dan UUPA. Penegasan bahwa anak dalam kandungan itu sudah merupakan manusia atau orang jelas terlihat dari ketentuan Pasal 1 angka 5 UUHAM yang menyatakan: "Anak adalah setiap manusia yang berusia di bawah 18 (delapan belas) tahun dan belum menikah, termasuk anak yang masih berada dalam kandungan apabila hal tersebut adalah demi kepentingannya". Demikian pula di dalam Pasal 1 angka 1 UUPA ditentukan: "Anak adalah seseorang yang belum berusia 18 (delapan belas) tahun, termasuk anak yang masih dalam kandungan."

Dengan demikian jelas terlihat bahwa hukum pidana positif Indonesia cenderung memberikan perlindungan hukum yang kuat terhadap hak hidup anak dalam kandungan. Jaminan terhadap pemenuhan hak asasi anak dalam kandungan dipertegas oleh ketentuan di dalam Pasal 1 angka 2 UUHAM dan Pasal 1 angka 12 UUPA. Apabila terjadi pelanggaran terhadap hak asasi anak dalam kandungan, maka terhadap si pelaku diancam dengan sanksi pidana, bahkan apabila pelakunya adalah orang tuanya sendiri maka sanksi pidana diperberat sepertiganya sebagaimana diatur dalam Pasal 80 ayat (1), (2), (3) dan (4) UUPA.

\section{Pembenaran Medis tentang Kapan Kehidupan Dimulai}

Menurut Mardjono Reksodiputro, ${ }^{6}$ ilmu hukum pidana yang mencoba mengatur persoalan perlindungan terhadap anak dalam kandungan mengambil sikap bahwa sejak kandungan itu diterima sebagai dipersamakan dengan orang dalam ilmu hukum, maka sejak itu pulalah kandungan berhak atas perlindungan hak asasinya sebagaimana diberikan kepada setiap orang dalam masyarakat pada umumnya. Mengenai sejak kapan kandungan itu hidup janganlah dipersoalkan oleh ilmu hukum. Ilmu hukum, khususnya hukum pidana berkepentingan untuk turut campur dalam perlindungan hak-hak kandungan, khususnya mengenai perlindungan hukum atas jiwa. Untuk mengetahui sejak kapan kandungan itu hidup, ilmu hukum sebaiknya berpaling dan meminta bantuan pada ilmu kedokteran.

${ }^{6}$ Mardjono Reksodiputro, "Pembaharuan Hukum Pengguguran Kandungan", dalam Departemen Kesehatan R.I., Kumpulan Naskah-Naskah Ilmiah dalam Simposium Abortus di Surabaya Tanggal 2 Agustus 1973, Bagian Penerbitan dan Perpustakaan Biro V, Jakarta, 1974, hlm. 6. 
Pendapat Mardjono Reksodiputro di atas bahwa untuk mengetahui sejak kapan kandungan itu hidup, ilmu hukum sebaiknya berpaling dan meminta bantuan pada ilmu kedokteran. Sejalan dengan salah satu kesimpulan hasil penelitian Bekti Dwi Andari, dkk., ${ }^{7}$ bahwa ketiga agama (Islam, Kristen, dan Katolik) mempunyai dasar pijak mengenai konsep kehidupan yang berbeda-beda bergantung pada tafsir atas teks keagamaan. Meski demikian, dari ketiganya terdapat benang merah bahwa objektivisasi penentuan kehidupan didasarkan pada pembenaran medis.

Oleh karena itu sangat diperlukan kajian medis mengenai konsep kehidupan itu. Di dalam Seminar Nasional mengenai Aborsi Legal di Indonesia Perspektif Hukum Pidana, Medis, Psikiatri \& Sosial serta Opini Publik yang Berkembang Dalam Masyarakat yang diselenggarakan oleh Bagian Hukum Pidana Fakultas Hukum Universitas Atma Jaya Yogyakarta, 24 Februari 2005 di Yogyakarta. Sulchan Sofoewan ${ }^{8}$ dalam makalah yang berjudul "Kapan Dimulainya Kehidupan, Tahap-Tahap Kehidupan Janin Dalam Kandungan dan Aborsi Legal Perspektif Medis" menyatakan bahwa "awal kehidupan adalah sejak bertemunya ovum dengan spermatozoon dan menjadi zygote" dalam suatu proses sebagai berikut: "Pada saat sebuah sel telur (ovum) yang masak dari follikel di indung telur (ovarium), ia masih dalam metafasis pembelahan meiosis II. Dengan masuknya sebuah spermatozoon (pembuahan), ia melepaskan benda polar II, dan berakhirlah meiosis II. Peristiwa ini disebut aktivasi telur. Intinya segera berubah menjadi pronukleus betina, sementara spermatozoon setelah melepaskan ekornya, berubah menjadi pronukleus jantan. Kedua pronukleus akhirnya melebur ditengahtengah sitoplasma sel telur dan terjadilah zygote, sebuah sel tunggal, awal dari kehidupan baru makluk manusia."

Menurut CB Kusmaryanto, ${ }^{9}$ zygot yang masih sangat kecil itu sudah membentuk susunan genetiknya tersendiri yang tidak sama dengan orang tuanya. Dia berkembang (membelah diri) dengan memakai energi yang ada di dalam sel itu sendiri, tanpa harus mendapatkannya dari luar. Ia juga berkembang menurut programnya sendiri, yang tertulis di dalam kode genetiknya sendiri, yang terbentuk ketika selesainya proses pembuahan. Dengan kata lain, zygot itu sudah mandiri

${ }^{7}$ Bekti Dwi Andari dkk., Aborsi dalam Perspektif Lintas Agama, Kerjasama Ford Foundation dengan PSKK UGM, Yogyakarta, 2005, hlm. 138-139.

${ }^{8}$ Sulchan Sofoewan, "Kapan Dimulainya Kehidupan, Tahap-tahap Kehidupan Janin Dalam Kandungan dan Aborsi Legal Perspektif Medis”, disampaikan dalam Seminar Nasional “Aborsi Legal di Indonesia Perspektif Hukum Pidana, Medis, Psikiatri \& Sosial Serta Opini Publik Yang Berkembang dalam Masyarakat”, Bagian Hukum Pidana FH UAJY, Yogyakarta, 24 Februari 2005, hlm. 1. 
dan menjadi individu baru. Secara singkat bisa dikatakan, bahwa ketika selesai fusi sel telur dan sperma ini, maka seluruh masa depan orang itu sudah ada di dalamnya, sebab potensi aktif manusia sudah ada, hanya tinggal menunggu perkembangan lebih lanjut untuk mewujudkan manusia seutuhnya.

Sulchan Sofoewan ${ }^{10}$ menjelaskan pula tentang perkembangan embrio dan janin sebagai berikut:

0-4 minggu : terjadi fertilasi, embrio berjalan dalam tuba fallopii dan berimplantasi pada dinding uterus, mulai terbentuk susunan syaraf, otak, percernaan, telinga, lengan dan mata; hari ke-25 jantung mulai berdenyut.

5 -8 minggu : lubang hidung, kelopak mata, hidung, jari tangan, tungkai, jari kaki dan tulang mulai terbentuk, pada wanita ovariumnya dan pada pria testisnya berkembang, kepala lebih besar; sistem kardiovaskular berfungsi penuh pada saat panjang badan sekitar $22 \mathrm{~mm}$.

9 - 12 minggu : embrio menjadi janin sejak 8 minggu sampai lahir; penis, dagu dan struktur muka sudah mulai tampak, kepala masih dominan, panjang badan kira-kira: $36 \mathrm{~mm}$.

13 - 16 minggu: mengejapkan mata, mengisap, tumbuh cepat, ibu merasakan aktivitas janin, panjang badan sekitar: $140 \mathrm{~mm}$.

17 - 20 minggu: anggota badan sudah proporsional, kening mata, panjang panjang badan sekitar: $190 \mathrm{~mm}$.

21 - 30 minggu: berat terus bertambah, kulit berkerut warna merah, panjang badan sekitar: $280 \mathrm{~mm}$.

30 - 40 minggu: kuku jari tangan dan jari kaki mulai tumbuh, panjang badan sekitar: $360 \mathrm{~mm}$.

Plasenta adalah organ embrio yang berfungsi untuk: pernafasan, nutrisi dan ekskresi darah janin dan darah ibu tidak bercampur. Tali pusat yang berisi 2 arteri dan 1 vena. Ketika umur mencapai 270 hari sejak fertilasi, janin sudah cukup bulan dan siap untuk dilahirkan.

Pernyataan Sulchan Sofoewan dan CB Kusmaryanto bahwa awal kehidupan manusia itu dimulai sejak konsepsi didukung pula oleh pernyataan di dalam beberapa artikel yang dimuat di beberapa jurnal seperti: "The Unborn Child is a Human Being from the Beginning" yang dimuat dalam HUMAN LIFE OF WASHINGTON, "The Beginning of a Human Life" yang ditulis oleh Billings dan dimuat dalam LIFE ISSUES, dan "The Beginning of Life" yang dimuat dalam ISLAM-SET-BIOETHICSOBSTETRICS and GYNAECOLOGY.

Di dalam artikel "The Unborn Child is a Human Being from the Beginning" yang dimuat dalam HUMAN LIFE OF WASHINGTON,11 antara lain dinyatakan sebagai berikut:

\footnotetext{
${ }^{9}$ CB Kusmaryanto, Kontroversi Aborsi, Grasindo, PT Gramedia Widiasarana Indonesia, Jakarta, 2002, hlm. 69-70.

${ }^{10}$ Sulchan Sofoewan, Op. Cit., hlm. 3.
} 
"When the male and female sex cells merge, an individual organism's life begins. Conception. Before then, no genetically unique individual exists. After the biological fact of conception, a person's one-of-a-kind genetic code begins the development process - a process that begins with incredibly rapid cellular growth and ends about the age 20 when the brain is fully developed. Every other developmental event pales in comparison to an individual's conception." (Ketika sel kelamin jantan dan perempuan bergabung pada saat konsepsi dimulailah kehidupan makluk individu. Sebelum itu tidak ada individu yang unik secara genetik. Setelah konsepsi yang merupakan kenyataan biologis, dimulailah proses perkembangan kode genetik satu jenis orang - proses yang dimulai dengan perkembangan sel yang luar biasa cepat dan berhenti pada usia sekitar 20 hari ketika otak telah berkembang secara penuh. Setiap perkembangan lainnya tidak berarti bila dibandingkan dengan konsepsi individu.)

Di dalam artikel "The Beginning of a Human Life" yang ditulis oleh Billings ${ }^{12}$ antara lain disebutkan:

"When we are talking about the beginning of a human life we are talking about this cell - the zygote (which means yolked together) and defined in the medical dictionary as an organism produced by the union of two gamets - in other words, the earliest form of the embryo." (Apabila kita bicara tentang awal kehidupan manusia yang kita bicarakan adalah sel - zygot (yang berarti dilekatkan bersama) dan di dalam kamus medis didefinisikan sebagai makluk hidup hasil perpaduan sel telur dan sperma -itulah bentuk awal embrio).

Demikian pula di dalam artikel berjudul "The Beginning of Life" yang dimuat dalam ISLAM-SET-BIOETHICS-OBSTETRICS and GYNAECOLOGY ${ }^{13}$ antara lain dinyatakan:

"Various treatises on medical ethics exibit a spectrum of definitions for the beginning of life. Fertilization, nidation, taking shape, quickening, ensoulment have all been adopted by various authors probably influenced by their convictions concerning the subjects we alluded to. Setting personal convictions or ideosyncracies aside, it seems to us that the phases of life of an individual qualifying to be considered its beginning, should combine all of the following criteria: (1) It should be a clear and well defined event that can actually be pointed at to be called the beginning of life. (2) It should exhibit that cardinal feature of beginning life viz "growth." (3) If this growth is not interrupted, it will naturally lead up to the subsequent stages of life as we know them: fetus, neonate, child, adolescent, adult, old ...until death. (4) It contains the genetic bag that is characteristics of the human race at large and also of a unique particular individual of whom no other human being is a perfect copy, since eternity and until eternity. It is not preceded by another phase which combines all the preceding characteristics from 1 to 4.

Applying these criteria, life begins with the fusion of a spermatozoan with an ovum to form the zygote, endowed with forty six chromosomes, half maternal and half peternal. Neither sperm nor unfertilized ovum fulfil the criteria although they are alive. Subsequent stages do not qualify because they are preceded by the zygote that fulfils all criteria."

\footnotetext{
${ }^{11}$ http://www.human life.net/abortion articles/beginning.html: 29/01/2005, hlm. 2-3.

${ }^{12}$ Human Life Of Washington, "The Unborn Child is a Human Being from the Beginning," http://www.human life.net/abortion articles/beginning.html: 29 Januari, 2005, hlm. 1-8.

${ }^{13}$ Islam-Set-Bioethics-Obstetrics and Gynaecology, "The Beginning of Life," http:/ /www.islamset.com/bioethics/obstet/beginn.html: 21 Februari 2005, hlm. 1.
} 
(Berbagai tulisan mengenai etika medis memperlihatkan berbagai spektrum definisi awal kehidupan. Pembuahan, nidasi, berbentuk, gerakan awal, penghembusan roh telah diadopsi berbagai penulis mungkin dipengaruhi oleh pendirian mereka mengenai subjek yang kita singgung. Dengan menyampingkan pendirian dan keistimewaan pribadi, tampaknya bagi kita bahwa tahap kehidupan individu yang memenuhi syarat untuk dipertimbangkan sebagai awalnya, harus mengkombinasikan semua kriteria berikut ini: (1) harus ada peristiwa yang jelas dan didefinisikan secara baik sehingga dapat secara nyata dikatakan awal kehidupan. (2) Harus ditunjukkan bahwa ciri pokok awal kehidupan yaitu "pertumbuhan." (3) Apabila pertumbuhan ini tidak dihentikan, secara alamiah ia akan berkembang ke tahap-tahap kehidupan berikutnya: janin, bayi yang baru lahir, anak, remaja, dewasa, tua ... sampai kematian. (4) Pertumbuhan itu berisikan kantung genetik yaitu ciri ras manusia pada umumnya dan ciri individu khusus yang unik dan tidak bisa menjadi kopi yang sempurna dari manusia lainnya dan itu adalah kekal dan abadi. (5) Pertumbuhan itu tidak didahului oleh tahap lain yang mengkombinasikan semua ciri awal dari 1 sampai 4).

Melalui penerapan kriteria ini, kehidupan itu dimulai ketika terjadi fusi antara sel sperma dan sel telur untuk membentuk zygot yang diberkahi 46 kromosom, separuh milik ibu, separuh milik ayah. Baik sperma maupun ovum yang tidak dibuahi tidak memenuhi kriteria ini meskipun mereka hidup. Tahap-tahap berikutnya tidak memenuhi syarat karena mereka didahului oleh zygot yang memenuhi seluruh kriteria).

Dari uraian di atas jelas bahwa kehidupan itu telah dimulai sejak konsepsi karena zygot itu sudah mandiri dan menjadi individu baru, dan potensi aktif manusia sudah ada, hanya tinggal menunggu perkembangan lebih lanjut unuk mewujudkan manusia seutuhnya. Oleh karena itu hukum, dalam hal ini hukum pidana berkepentingan untuk turut campur dalam perlindungan hak-hak kandungan, khususnya mengenai perlindungan hukum atas jiwa anak dalam kandungan.

\section{Hukum yang Seharusnya Berlaku (Ius Constituendum) untuk Memberikan Perlindungan terhadap Anak dalam Kandungan}

Indonesia bukan negara yang melegalkan aborsi seperti Amerika Serikat dan Belanda. Dikatakan demikian karena aborsi di Amerika Serikat dilegalkan berdasarkan putusan MA AS pada 22 Januari 1973 dalam perkara Roe v. Wade dan Doe v. Bolton. Sedangkan Belanda, negara asal KUHP, telah melegalkan aborsi dengan Undang-Undang Pengguguran Kandungan 1 Mei Stb. 1981, 257 yang kemudian diubah dengan Undang-Undang 6 Nopember 1997, Stb. 1997, 510. Namun dengan adanya ketentuan Pasal 75 ayat (1) b UU No. 36 Tahun 2009 tentang Kesehatan (UUK) 
yang membolehkan aborsi karena kehamilan akibat perkosaan, dapat dikatakan bahwa Indonesia telah mengarah ke legalisasi aborsi. Oleh karena itu UUK sejak masih berbentuk draf RUU Kesehatan telah ditentang oleh kubu Pro-Life. Bahkan menurut Ribka Tjiptaning, ${ }^{14}$ Ketua Komisi IX yang juga Ketua Panitia Khusus Komisi IX untuk pembahasan RUU Kesehatan, dalam Rapat Kerja Komisi IX dengan Menteri Kesehatan, 8 fraksi menerima RUU Kesehatan, 1 fraksi, yakni Partai Bintang Reformasi (PBR), menerima dengan catatan, sementara Partai Damai Sejahtera (PDS) menolak, keduanya terkait dengan pasal-pasal mengenai kesehatan reproduksi, khususnya aborsi.

Dalam sidang pleno, PDS akhirnya menerima RUU Kesehatan. Namun terkait dengan aborsi, PDS hanya menerima Pasal 75 ayat (2) a, yang mengatur indikasi kedaruratan medis yang dideteksi sejak usia dini kehamilan, baik yang mengancam nyawa ibu dan/atau janin. Senada dengan itu, PBR memberi catatan yang menolak aborsi untuk kehamilan akibat perkosaan, dengan menggunakan alasan hak hidup untuk janin.

Catatan penolakan fraksi PBR dan PDS terhadap Pasal 75 ayat (2) b UUK dapat dipahami karena dari ketentuan UUD 1945 terlihat bahwa Pasal 28A mengatur tentang perlindungan orang pada umumnya dan Pasal 28B ayat (2) mengatur tentang perlindungan anak pada khususnya. Dari kedua ketentuan ini dapat dikatakan bahwa Republik Indonesia sebagai negara hukum jelas memuat perlindungan hukum atas hak-hak asasi orang, yang berarti adanya perlindungan konstitusi terhadap 'orang' di Indonesia. Dan inti perlindungan konstitusi itu adalah bahwa negara tidak boleh melakukan diskriminasi dan mengurangi hak seseorang atas jiwa, kemerdekaan dan milik tanpa melalui 'due process of law,' termasuk di dalamnya pengurangan hak hidup anak dalam kandungan tanpa melalui proses hukum yang layak, meskipun kehamilan itu adalah hasil perkosaan.

Perlindungan konstitusi ini mencakupi pembatasan terhadap negara untuk mengundangkan hukum secara sewenang-wenang dan yang menghilangkan kesempatan tata cara yang memungkinkan yang bersangkutan memberikan pembelaan yang wajar terhadap tindakan yang akan dijalankan terhadapnya. Dalam rangka uraian ini maka dapat dikatakan bahwa adalah bertentangan dengan perlindungan konstitusi yang merupakan hak setiap orang, apabila diundangkan

${ }^{14}$ Ribka Tjiptaning, "RUU Kesehatan Disabkan”, Harian KOMPAS, 15 September 2009, hlm. 14. 
suatu peraturan yang secara sewenang-wenang memungkinkan hilangnya nyawa orang tanpa yang bersangkutan diberi cukup kesempatan untuk membela dirinya melalui upaya-upaya hukum. Singkatnya dapat diketengahkan, bahwa perundangundangan yang memungkinkan 'hilangnya nyawa kandungan' secara sewenangwenang dan tanpa pemberian kesempatan pembelaan yang cukup adalah melanggar hak asasi kandungan yang dilindungi konstitusi. ${ }^{15}$

Bertolak dari analisis Mardjono Reksodiputro di atas, maka dapat dipahami penolakan kedua fraksi tersebut terhadap Pasal 75 ayat (2) b UUK. Dikatakan demikian karena menurut kedua fraksi tersebut dengan adanya Pasal 75 ayat (2) b UUK negara telah mengundangkan hukum secara sewenang-wenang dan menghilangkan nyawa kandungan, karena meskipun kehamilan itu akibat perkosaan, janin yang dikandung itu mempunyai hak hidup dan tidak bersalah, maka harus diberikan kesempatan pembelaan yang cukup agar tidak melanggar hak asasi kandungan yang dilindungi konstitusi. Atau meminjam istilah Topo Santoso dan Eva Achjani Sulfa, ${ }^{16}$ negara telah menjadi homo homini lupus bagi warganya sendiri karena telah mengundangkan hukum yang secara sewenang-wenang menghilangkan nyawa orang.

L. Oppenheim ${ }^{17}$ pernah mengatakan bahwa hukum adalah "a body of rules for human conduct within a community which by common consent of that community shall be enforced by external power" (kumpulan ketentuan-ketentuan untuk mengatur tingkah laku manusia dalam suatu masyarakat yang berdasarkan persetujuan bersama dari masyarakat tersebut harus dipaksakan berlaku oleh kekuatan eksternal). Dari rumusan itu tampak bahwa inti pengertian hukum itu adalah ketentuan-ketentuan (rules). Karena ketentuan-ketentuan itu menetapkan hak dan kewajiban, maka inti ketentuan-ketentuan itu adalah hak dan kewajiban hukum.

Perumusan yang menyatakan hukum merupakan ketentuan yang harus dipaksakan berlaku itu sekilas menunjukkan kaitan hukum sebagai ketentuan (das sollen) dengan kenyataan (das sein) yang merupakan perwujudan dari ketentuan tersebut. Kehidupan hukum memang terkait pada hubungan sollen-sein itu. Dari kenyataan (das sein) ditetapkan ketentuan hukum (das sollen) dan dari ketentuan hukum (das sollen) diwujudkan menjadi kenyataan (das sein).

\footnotetext{
${ }^{15}$ Mardjono Reksodiputro, Op.Cit., hlm. 5.

${ }^{16}$ Topo Santoso dan Eva Achjani Sulfa, Kriminologi, Divisi Buku Perguruan Tinggi PT RajaGrafindo Persada, Jakarta, 2002, hlm 3.

${ }^{17}$ L. Oppenheim, International Law; A Treatise, Vol.1-Peace, Eight Edition, H. Luterpacht (ed), Longmans, Green and Co., New York, 1955, hlm. 8.
} 
Hubungan das sollen-das sein yang demikian itu terlihat pula di dalam ketentuan hukum tentang perlindungan terhadap anak dalam kandungan. KUHP (das sollen) yang memuat larangan mutlak terhadap aborsi tanpa membedakan abortus provocatus criminalis dan abortus provocatus medicinalis/therapeuticus menghadapi kenyataan (das sein) bahwa aborsi perlu dilakukan terhadap perempuan yang hamil akibat perkosaan dan karenanya mengalami trauma berat. Maka dari sein tersebut dibentuklah ketentuan hukum das sollen yaitu UUK yang membolehkan aborsi berdasarkan ketentuan Pasal 75 ayat (2) a dan b apabila memenuhi persyaratan sebagaimana ditentukan dalam Pasal 76.

Ternyata ketentuan Pasal 75 ayat (2) b UUK (das sollen) dalam kenyataan (das sein) menghadapi tantangan berupa penolakan kubu Pro-Life di dalam masyarakat dan catatan penolakan oleh fraksi PBR dan PDS di forum DPR karena dinilai tidak sinkron dengan peraturan perundang-undangan yang ada baik secara horizontal maupun vertikal. Dikatakan demikian karena secara horizontal ketentuan Pasal 75 ayat (2) b UUK bertentangan dengan Pasal 1 angka 5 UUHAM dan Pasal 1 angka 1 UUPA dan secara vertikal bertentangan dengan Pasal 28B ayat (2) UUD 1945.

Ketentuan Pasal 75 ayat (2) b UUK yang secara vertikal bertentangan dengan Pasal 28B ayat (2) UUD 1945 dan secara horizontal bertentangan dengan Pasal 1 angka 2 UUHAM dan Pasal 1 angka 12 UUPA, dengan sendirinya atau (eo ipso) bertentangan pula dengan pernyataan pada alinea IV Pembukaan UUD 1945 yang memuat salah satu tujuan didirikannya Negara Republik Indonesia dan menjadi landasan politik hukum Indonesia yaitu "melindungi segenap bangsa dan seluruh tumpah darah Indonesia". Begitu umumnya perlindungan hukum yang diberikan oleh negara yaitu kepada segenap bangsa Indonesia dan tumpah darah Indonesia, maka dapat dikatakan bahwa perlindungan itu tidak hanya diberikan kepada orang pada umumnya, tetapi juga kepada anak dalam kandungan, temasuk di dalamnya janin yang merupakan hasil perkosaan, karena berdasarkan kajian medis kehidupan itu telah dimulai sejak konsepsi.

Bertolak dari uraian di atas jelas terlihat bahwa ketentuan Pasal 75 ayat (2) b UUK telah memunculkan ketidakpastian hukum dalam perlindungan hukum terhadap anak dalam kandungan. Dikatakan demikian karena negara sesungguhnya telah membuat ketentuan yang dimaksudkan untuk menghukum orang yang tidak bersalah tanpa melalui "due prosess of law" (mendapat perlindungan/pembelaan diri sebagai haknya). Bahkan ketentuan tersebut tidak mencerminkan Indonesia sebagai 
negara hukum, karena negara hukum (rechtsstaat) di dalam Kamus Umum BelandaIndonesia ${ }^{18}$ diartikan sebagai, negara yang mempertahankan dan melindungi hakhak warga negaranya.

Oleh karena itu untuk memberikan kepastian di bidang hukum mengenai perlindungan hukum yang layak terhadap anak dalam kandungan, keberadaan Pasal 75 ayat (2) b UUK perlu ditinjau kembali sehingga hukum yang seharusnya berlaku (ius constituendum) tentang perlindungan terhadap anak dalam kandungan akan sinkron dengan politik hukum Indonesia yang ditegaskan pada alinea IV Pembukaan UUD 1945, yaitu "melindungi segenap bangsa Indonesia dan seluruh tumpah darah Indonesia".

\section{Penutup}

Berdasarkan analisis sebagaimana diuraikan di atas, dapat disimpulkan sebagai berikut. Pertama, kehidupan itu telah dimulai sejak konsepsi, maka sejak itu pula hukum khususnya hukum pidana mempunyai kepentingan untuk melindungi anak dalam kandungan. Hukum positif telah menyesuaikan diri dengan ilmu pengetahuan kedokteran tentang perkembangan kehidupan anak dalam kandungan sehingga cenderung memberikan perlindungan yang kuat terhadap anak dalam kandungan. Kedua, ketentuan Pasal 75 ayat (2) b UUK secara horizontal bertentangan dengan Pasal 1 angka 5 UUHAM dan Pasal 1 angka 1 UUPA serta secara vertikal bertentangan dengan Pasal 28B ayat (2) UUD 1945. Akibatnya timbul ketidakpastian hukum dalam perlindungan hukum terhadap anak dalam kandungan.

Oleh karena itu untuk memberikan kepastian di bidang hukum mengenai perlindungan hukum yang layak terhadap anak dalam kandungan, keberadaan Pasal 75 ayat (2) b UUK perlu ditinjau kembali sehingga hukum yang seharusnya berlaku (ius constituendum) tentang perlindungan terhadap anak dalam kandungan akan sinkron dengan politik hukum Indonesia yang ditegaskan pada alinea IV Pembukaan UUD 1945.

${ }^{18}$ S. Wojowasito, Kamus Umum Belanda Indonsia, PT Ichtiar Baru - Van Hoeve, Jakarta, 1985, hlm. 532. 


\section{Daftar Pustaka}

Bellefroid, J.P.H., Inleiding Tot De Rechtswetenschap In Nederland, Dekker \& Van de Vegt N.V., Nijmegen,1953.

Billings, E. L., The Beginning of a Human Life, LIFE ISSUES, http: / /www.lifeissues.net/ writers/bil/bil_11mrslifebegiing.html, 29 Januari 2005.

Budi Utomo, A. Habsjah, K.N. Siregar, M. Budiharsana, dan D. Dachlia, Insiden dan Aspek Psiko-Sosial Aborsi di Indonesia (Prosiding Seminar), Pusat Penelitian Kesehatan Universitas Indonesia \& United Nations Population Fund (UNPA), Jakarta, 2001.

Dwi Andari, Bekti, L. Rohmaniah, B.R. Atmoko, N.E. Cahyawati, dan A.Aditomo, Aborsi dalam Perspektif Lintas Agama, Kerjasama Ford Foundation dengan PSKK UGM, Yogyakarta,2005.

Human Life Of Washington, "The Unborn Child is a Human Being from the Beginning." http:/ / www.human life.net/abortion articles/beginning.html: 29 Januari, 2005.

Islam-Set-Bioethics-Obstetrics and Gynaecology, "The Beginning of Life," http:// www.islamset.com/bioethics/obstet/beginn.html: 21 Februari 2005.

Kusmaryanto, CB., Kontroversi Aborsi, Grasindo, PT Gramedia Widiasarana Indonesia, Jakarta, 2002.

Nawawi Arief, Barda, Penetapan Pidana Penjara dalam Rangka Usaha Penanggulangan Kejahatan, Universitas Padjadjaran, Bandung, 1986.

Oppenheim, L. International Law; A Treatise, Vol.1-Peace, Eight Edition, H. Luterpacht (ed), Longmans, Green and Co., New York, 1955.

Reksodiputro, Mardjono, "Pembaharuan Hukum Pengguguran Kandungan", dalam Departemen Kesehatan R.I., Kumpulan Naskah-Naskah ilmiah Dalam Simposium Abortus di Surabaya Tanggal 2 Agustus 1973, Bagian Penerbitan dan Perpustakaan Biro V, Jakarta, 1974.

Ss., Soehardjo, Politik Hukum dan Pelaksanaannya Dalam Negara Republik Indonesia, Fakultas Hukum Undip, Semarang, tanpa tahun.

Santoso, Topo dan Eva Achjani Sulfa, Kriminologi, Divisi Buku Perguruan Tinggi PT RajaGrafindo Persada, Jakarta, 2002.

Sofoewan, Sulchan, “Kapan Dimulainya Kehidupan, Tahap-Tahap Kehidupan Janin Dalam Kandungan dan Aborsi Legal Perspektif Medis", disampaikan dalam Seminar Nasional "Aborsi Legal di Indonesia Perspektif Hukum Pidana, Medis, Psikiatri \& Sosial Serta Opini Publik Yang Berkembang dalam Masyarakat", Bagian Hukum Pidana FH UAJY, Yogyakarta, 24 Februari 2005.

Tjiptaning, Ribka, "RUU Kesehatan Disahkan”, Harian KOMPAS, 15 September 2009.

Wojowasito, S., Kamus Umum Belanda Indonesia, PT Ichtiar Baru - Van Hoeve, Jakarta, 1985. 